\title{
O ESTADO COMO ACIONISTA MINORITÁRIO EM EMPRESAS PRIVADAS
}

\section{THE STATE AS A MINORITY SHAREHOLDER IN PRIVATE COMPANIES}

\section{LEONARDO BALDISSERA}

Mestrando em Direito Empresarial e Cidadania pelo Centro Universitário Curitiba UNICURITIBA. Curitiba - PR. E-mail: baldisseraleo@gmail.com

\section{FERNANDO CESAR VELLOZO LUCASKI}

Mestrando em Direito Empresarial e Cidadania pelo Centro Universitário Curitiba UNICURITIBA. Curitiba - PR. E-mail: fernandolucaski@hotmail.com

\section{FERNANDO GUSTAVO KNOERR}

Professor Orientador - Centro Universitário Curitiba - UNICURITIBA. Curitiba - PR. E-mail: mestrado@unicuritiba.edu.br

\section{RESUMO}

A forma como o Estado intervém na economia vem sofrendo alterações substanciais nos últimos anos, observando-se uma forte tendência de se estabelecer parcerias com a iniciativa privada para o fim de desenvolver diversos setores da economia. Além disso, é possível constatar um crescente movimento no sentido de utilizar instrumentos próprios do direito privado para permitir ao Estado atuar com maior eficiência na economia. Nesse sentido é que foram estabelecidas diversas parcerias com empresas privadas na qual o Estado adquire parcela do capital social, sem, todavia, adquirir o poder de controle da empresa. Não que a aquisição do poder 


\section{Personalidade Acadêmica Homenageada:}

Raymundo Juliano Feitosa (Universidade Federal do Rio Grande do Norte - UFRN)

de controle seja vedada, mas não é um pressuposto para a consecução do negócio, pois caso fosse, se assemelharia as sociedades de economia mista. Essas novas parcerias permitem ao Estado atuar em determinados setores da economia de forma mais eficiente do que se fizesse pelos meios tradicionais, através dos entes de direito público ou mesmo por meio das empresas estatais, eis que as regras aplicáveis em tais casos, por vezes, são incompatíveis com a dinâmica do mercado e da atividade empresarial, movida pela busca incessante e necessária do lucro. Diante desse novo paradigma de atuação do Estado na economia surgiram também novos desafios regulatórios para conferir transparências e eficiente nas relações travadas entre o ente público e o privado. Nessa perspectiva, foi editada a Lei 13.303/2016 que regula diversos aspectos inerentes às empresas estatais, mas que também trouxe como inovação, regramento para estabelecer boas práticas de governança corporativa a serem adotadas nos casos em que o Estado se propõe a adquirir parcela do capital social de uma empresa privada. Muito embora a possibilidade do Estado participar como acionista ou quotista minoritário de empresas privadas esteja prevista na Constituição Federal, especificamente no artigo 37 , inciso XX, que trata também da criação de subsidiárias para empresas estatais, condicionando ambos os atos à autorização legislativa, a Lei 13.303/2016 denominada Lei das Estatais, que trata do regime jurídico aplicável às empresas públicas, sociedades de economia mista e subsidiárias, trouxe previsão idêntica ao do artigo 37 inciso $\mathrm{XX}$, da Constituição Federal, ressalvando, todavia, casos em que não é necessária a autorização legislativa para que a empresa estatal invista em uma empresa privada, conforme artigo $2^{\circ}$, $3^{\circ}$ da Lei 13.303/2016, dentre outros aspectos. A análise da legislação e doutrina pertinente permitiu observar que o regramento jurídico aplicável não pode seguir a rigidez das normas de direito público, mas também deve permitir que o Estado fiscalize, preste contas e tome as decisões de investimento e condução dos negócios da forma mais eficiente possível, sempre orientada pelo interesse público. As mudanças introduzidas pela Lei $13.303 / 2016$ no tocante às regras de governança corporativa ainda que não sejam autoaplicáveis, pois necessitam de adequação ao caso concreto, se mostram salutares e perfeitamente compatíveis com os novos 
Personalidade Acadêmica Homenageada:

Raymundo Juliano Feitosa (Universidade Federal do Rio Grande do Norte - UFRN)

arranjos societários existentes entre o Estado e iniciativa privada. Sendo importante destacar que o próprio regramento prevê que as regras devem ser adotadas de forma proporcional a relevância, materialidade e riscos do negócio, ou seja, ainda que se exija uma cautela e dever fiscalizatório por parte do Estado, as regras de governança corporativa não podem ser rígidas a ponto de inviabilizar a atividade econômica. Assim, é possível concluir que o legislador procurou disponibilizar instrumentos jurídicos que permitam ao Estado realizar os investimentos de forma mais eficiente possível na esfera privada, e em respeito aos princípios que regem a administração pública.

PALAVRAS-CHAVE: Lei das Estatais; Empresas privadas; Governança corporativa.

\section{REFERÊNCIAS}

ARAGÃO, Alexandre Santos de. Considerações Sobre as Relações do Estado e do Direito na Economia R. EMERJ, Rio de Janeiro, v. 20, n. 78, p. 168 - 187, Janeiro/Abril 2017.

CARVALHOSA. Modesto. Comentários à Lei de sociedades anônimas: Lie no 6.404 de 15 de dezembro de 1976. $2^{\underline{a}}$ ed. - São PAULO: Saraiva, 1998.

COMPARATO, Fábio Konder. SALOMÃO FILHO, Calixto. O poder de controle na sociedade anônima, 4 ed., Rio de Janeiro, ed. Forense, 2005.

DA SILVA, Marcos Alves; DE SÉLLOS KNOERR, Viviane Coêlho. Responsabilidade social da empresa e subcidadania pautas para uma reflexão de índole constitucional. Revista Jurídica - UNICURITIBA, v. 2, n. 31, p. 435-453, 2013.

GONÇALVES, Everton das Neves. Administração pública e a ação empresarial: consenso ético ou controle sobre a esfera privada? Revista Jurídica - UNICURITIBA, v. 2, n. 29, p. 72-93, 2012.

GUIMARÃES, Edgar; SANTOS, José Anacleto Abduch. Lei das Estatais: comentários ao regime jurídico licitatório e contratual da Lei no 13.303/2016. Belo Horizonte: Fórum. 2017. 
Personalidade Acadêmica Homenageada:

Raymundo Juliano Feitosa (Universidade Federal do Rio Grande do Norte - UFRN)

INSTITUTO BRASILEIRO DE GOVERNANÇA CORPORATIVA. Boas práticas de governança corporativa para sociedades de economia mista. / Instituto Brasileiro de Governança Corporativa; coord. Carlos Velloso. São Paulo, SP: IBGC, 2015. (Série Cadernos de Governança Corporativa, 14). 44p.

SCHWIND, Rafael Wallbach. Empresas estatais e empresas público-privadas: novos desafios da atuação empresarial do estado. Revista de Direito Administrativo Contemporâneo/ coord. Marçal Justen Filho. v. 22. São Paulo, 2016 